\title{
Article \\ Evaluating the Sustainability and Inherent Safety of a Crude Palm Oil Production Process in North-Colombia
}

\author{
Angel Darío González-Delgado ${ }^{1, *}$, Andrés F. Barajas-Solano ${ }^{2}$ (I) and Jeffrey Leon-Pulido ${ }^{3}$ \\ 1 Nanomaterials and Computer Aided Process Engineering Research Group (NIPAC), \\ Chemical Engineering Department, University of Cartagena, Cartagena de Indias 130015, Colombia \\ 2 Environment and Life Research Group, Department of Environmental Sciences, \\ Universidad Francisco de Paula Santander, Cúcuta 540003, Colombia; andresfernandobs@ufps.edu.co \\ 3 Chemical Engineering Program, EAN University, Bogotá 110221, Colombia; jleonp@universidadean.edu.co \\ * Correspondence: agonzalezd1@unicartagena.edu.co
}

Citation: González-Delgado, A.D.; Barajas-Solano, A.F.; Leon-Pulido, J. Evaluating the Sustainability and Inherent Safety of a Crude Palm Oil Production Process in North-Colombia. Appl. Sci. 2021, 11, 1046. https://doi. org/10.3390/app11031046

Received: 14 October 2020 Accepted: 28 December 2020 Published: 25 January 2021

Publisher's Note: MDPI stays neutral with regard to jurisdictional clai$\mathrm{ms}$ in published maps and institutional affiliations.

Copyright: () 2021 by the authors. Licensee MDPI, Basel, Switzerland. This article is an open access article distributed under the terms and conditions of the Creative Commons Attribution (CC BY) license (https:// creativecommons.org/licenses/by/ $4.0 /)$.

\begin{abstract}
The African palm is the main source of vegetable oil worldwide, representing about $29.60 \%$ of the total oil and fat production around the world. The rapid expansion of this sector has faced several concerns related to environmental and social aspects that have driven the search for sustainable alternatives. In this work, the inherent safety analysis and sustainability evaluation for the crude palm oil production process was performed using the inherent safety index (ISI) method and the sustainable weighted return on investment metric (SWROIM), respectively. The process was designed for a processing capacity of $30 \mathrm{t} / \mathrm{h}$ of palm bunches and under North-Colombian conditions. Three technical indicators were considered to evaluate the process sustainability including exergy efficiency, potential environmental impacts output (PEI output), and the total inherent safety index $\left(\mathrm{I}_{\mathrm{TI}}\right)$. The economic factor is directly considered since the SWROIM is an extension of the conventional return on investment (ROI). The resulting $\mathrm{I}_{\mathrm{TI}}$ at 11 indicated an inherently safe process, and the highest risk was observed for the process equipment safety subindex. The SWROIM reached a higher value (53\%) compared to the conventional ROI $(49.39 \%)$, which suggests positive impacts on sustainability. The novelty of this work lies in detecting the inherent risks and providing a decision making criteria for this project through a complete evaluation that relates economic, energy, environmental, and safety criteria.
\end{abstract}

Keywords: SWROIM; ROI; exergy efficiency; risks; African palm

\section{Introduction}

The African palm is the main source of vegetable oil worldwide, representing about $29.60 \%$ of the total oil and fat production around the world [1]. Consumption of crude palm oil reached 60,095 million tons by 2015 [2]. This consumption rate is related to its versatility, high productivity, and lower production cost. Indonesia (10,830,000 ha) and Malaysia (5,150,000 ha) are the countries with the largest production with approximately $78 \%$ of the global production area, while Colombia is the fifth-largest crude palm oil producer in the world and the first in Latin America with $2.30 \%$ of the global production area (465,000 ha) [3]. These plantations are located in four main regions of Colombia: north, center, east, and southwest [4]; however, the largest planted area occurs in the north of the country, accounting for $29 \%$ of total area [5]. The crude palm oil production represents an important economic activity for the socio-economic growth of the country [6]. Palm oil production has increased in recent years, driven by the demands from developing countries such as China, India, and Brazil [7]. An increase in African palm planted area to 2 million hectares is also expected in the coming years [8]. The rapid expansion of this sector has led to several environmental and social concerns such as greenhouse gas emission, waste generation, deforestation, biodiversity, and soil quality loss and land-use change [9]. 
The development of sustainable alternatives for palm industry has become a priority. Several works have been addressed to evaluate economic, energy, environmental, and social aspects of these bioenergy systems and identify improvement opportunities. For example, Gonzalez-Delgado and Peralta-Ruiz [10] carried out an environmental analysis using the Waste Reduction Algorithm (WAR) to quantify the rate of emission and generation of environmental impacts in the crude palm oil production. Martinez et al. [11] performed the exergy analysis to identify the main sinks of energy and process inefficiency; while Gonzalez-Delgado and Peralta-Ruiz [12] developed the techno-economic evaluation to determine the profitability of the process. Other studies addressed to evaluate the crude palm oil production are presented in Table 1.

Table 1. Recent works addressing bioenergy systems in the oil palm industry.

\begin{tabular}{|c|c|c|c|c|c|}
\hline Case Study & Location & Purpose & Method & Relevant Results & Reference \\
\hline $\begin{array}{l}\text { Oil palm } \\
\text { supply chain }\end{array}$ & Malasia & $\begin{array}{l}\text { Analyze the water } \\
\text { footprint (WFP) }\end{array}$ & $\begin{array}{c}\text { Water accounting and } \\
\text { vulnerability evaluation } \\
\text { (WAVE) }\end{array}$ & $\begin{array}{l}33 \% \text { reduction in } \\
\text { WFP when there was } \\
\text { no dilution at the mill }\end{array}$ & $\begin{array}{l}\text { Subramaniam } \\
\text { et al. [13] }\end{array}$ \\
\hline $\begin{array}{l}\text { Crude palm } \\
\text { oil production }\end{array}$ & Colombia & $\begin{array}{l}\text { Determine greenhouse } \\
\text { gas emissions and } \\
\text { economic profitability }\end{array}$ & $\begin{array}{l}\text { Life-cycle assessment } \\
\text { and economic analysis }\end{array}$ & $\begin{array}{c}\text { Net energy gain }= \\
12.5,13.7 \\
\text { Internal Rate of } \\
\text { Return }=34 \%, 43 \%\end{array}$ & $\begin{array}{l}\text { Ramirez- } \\
\text { Contreras } \\
\text { et al. [9] }\end{array}$ \\
\hline $\begin{array}{l}\text { Crude palm oil } \\
\text { production }\end{array}$ & Colombia & $\begin{array}{l}\text { Analyze potential } \\
\text { process hazards }\end{array}$ & $\begin{array}{l}\text { Hazard Identification } \\
\text { and Ranking (HIRA) }\end{array}$ & $\begin{array}{l}\text { Fire and Explosion } \\
\text { Damage Index }=400\end{array}$ & $\begin{array}{l}\text { Moreno-Sader } \\
\text { et al. [14] }\end{array}$ \\
\hline $\begin{array}{l}\text { Crude palm and } \\
\text { kernel oil } \\
\text { production }\end{array}$ & Colombia & $\begin{array}{l}\text { Quantify potential } \\
\text { environmental } \\
\text { impacts (PEI) }\end{array}$ & $\begin{array}{l}\text { Waste Reduction } \\
\text { (WAR) Algorithm }\end{array}$ & $\begin{array}{c}\text { Output rate of PEI = } \\
1.66 \times 10^{-4} \mathrm{PEI} / \mathrm{h}\end{array}$ & $\begin{array}{c}\text { Alvarez-Cordero } \\
\text { et al. [15] }\end{array}$ \\
\hline $\begin{array}{l}\text { Oil palm } \\
\text { supply chain }\end{array}$ & Brazil & $\begin{array}{c}\text { Evaluate process } \\
\text { sustainability }\end{array}$ & $\begin{array}{l}\text { Life-cycle assessment, } \\
\text { Socio economic analysis }\end{array}$ & $\begin{array}{c}\text { Bluewater footprint }= \\
6.8 / \mathrm{L} \text { oil }\end{array}$ & $\begin{array}{l}\text { Munasinghe } \\
\text { et al. [16] }\end{array}$ \\
\hline $\begin{array}{l}\text { Crude palm oil } \\
\text { production }\end{array}$ & Brazil & $\begin{array}{l}\text { Perform greenhouse } \\
\text { gas (GHG) balance }\end{array}$ & Life-cycle assessment & $\begin{array}{l}\mathrm{GHG}=-208 \mathrm{~kg} \mathrm{CO}_{2^{-}} \\
\text {equiv./1000 kg palm }\end{array}$ & $\begin{array}{l}\text { Oliveira } \\
\text { et al. [17] }\end{array}$ \\
\hline
\end{tabular}

In this work, an inherent safety analysis and sustainability evaluation is performed for a crude palm oil production process under North Colombian conditions. The inherent safety analysis allows us to avoid hazards by reducing dangerous material and the number of hazardous operations in the plant [18], while sustainability evaluation allows the complete analysis of the process including economic, environmental, safety, and energy criteria. San Juan et al. [19] performed the inherent safety for a bioethanol production process, while Meramo et al. [20] for a levulinic acid production process; in both cases, the processes showed good performance from a safety point of view. The sustainable weighted return on investment metric was used by Meramo-Hurtado et al. [21] to carry out the sustainability assessment of a lignocellulosic multifeedstock and to compare biobutanol production pathways via acetone-butanol-ethanol fermentation. A higher process performance of this system was observed by the authors using the SWROIM metric. The novelty of this work lies in detecting the inherent risks and determining the sustainability of the process through a complete evaluation that relates economic, energy, environmental, and safety criteria.

\section{Materials and Methods}

The methodology performed in this study encompasses the safety analysis and the sustainability evaluation for a crude palm oil production process under North-Colombian conditions. The inherent safety analysis was performed using the inherent safety index (ISI) methodology; while the sustainable weighted return on investment metric (SWROIM) was used as the tool to perform the sustainability evaluation. The criteria considered to evaluate the sustainability of the process were economic, environmental, energy, and safety. The technical indicators to evaluate the sustainability of the process included the exergy efficiency, potential environmental impacts output (PEI output), and the total inherent 
safety index $\left(\mathrm{I}_{\mathrm{TI}}\right)$. The economic factor was included directly in the SWROIM and was evaluated through the return on investment (ROI). The ROI, the exergy efficiency, and the PEI output were gathered from the techno-economic evaluation, exergy analysis, and environmental analysis previously performed by Gonzalez-Delgado and Peralta-Ruiz [12], Martinez et al. [11], and Gonzalez- Delgado and Peralta-Ruiz [10], respectively. The process and methodology used for the evaluations are described below.

\subsection{Process Description}

The process was modeled using as reference two extraction plants of crude palm oil located in Bolivar and Cesar departments in North Colombia and complementary data reported in the literature [22]. The processing of palm fruit into crude palm oil involves five basic operations: sterilization, threshing, fruit digestion, oil extraction, and oil purification [23], as shown in Figure 1. The African palm bunch $(30 \mathrm{t} / \mathrm{h})$ is sterilized by the action of saturated steam to avoid the effect of the enzyme lipase on the free fatty acids and to hydrolyze the palm rachis to soften the pulp tissues [15]. From the sterilization stage, the sterilized bunch, condensed water, and steam leave the system. Then, the sterilized bunches are sent to the threshing stage where the fruits are separated from the rachis by a rotating drum of $5 \mathrm{~kW}$ power. The rachis is discarded while the fruits are reheated in the digestion stage to facilitate the expulsion of the oil. The digestion equipment power is $10.5 \mathrm{~kW}$. The digested fruits are pressed by a horizontal perforated basket cylindrical shape, where a liquor containing a large amount of oil is extracted. Subsequently, water is added to the liquor to facilitate oil separation and purification. In the clarification stage, up to $90 \%$ of the oil is separated and sent to a drying process. The heavy sludge from the clarification goes to the centrifugation step where $10 \%$ of the oil is recovered; the water and heavy sludge from this stage leave the process, while the recovered oil is recirculated to the clarification stage. In the drying stage, the percentage of moisture and impurities still contained in the oil is reduced to the maximum; due to the high temperature at which the oil leaves, this drying is performed under vacuum conditions, the pressure of the stream is reduced and causes the remaining water to evaporate. The vacuum dryer power is $15 \mathrm{~kW}$. Finally, the dry palm oil is sent to its respective storage.

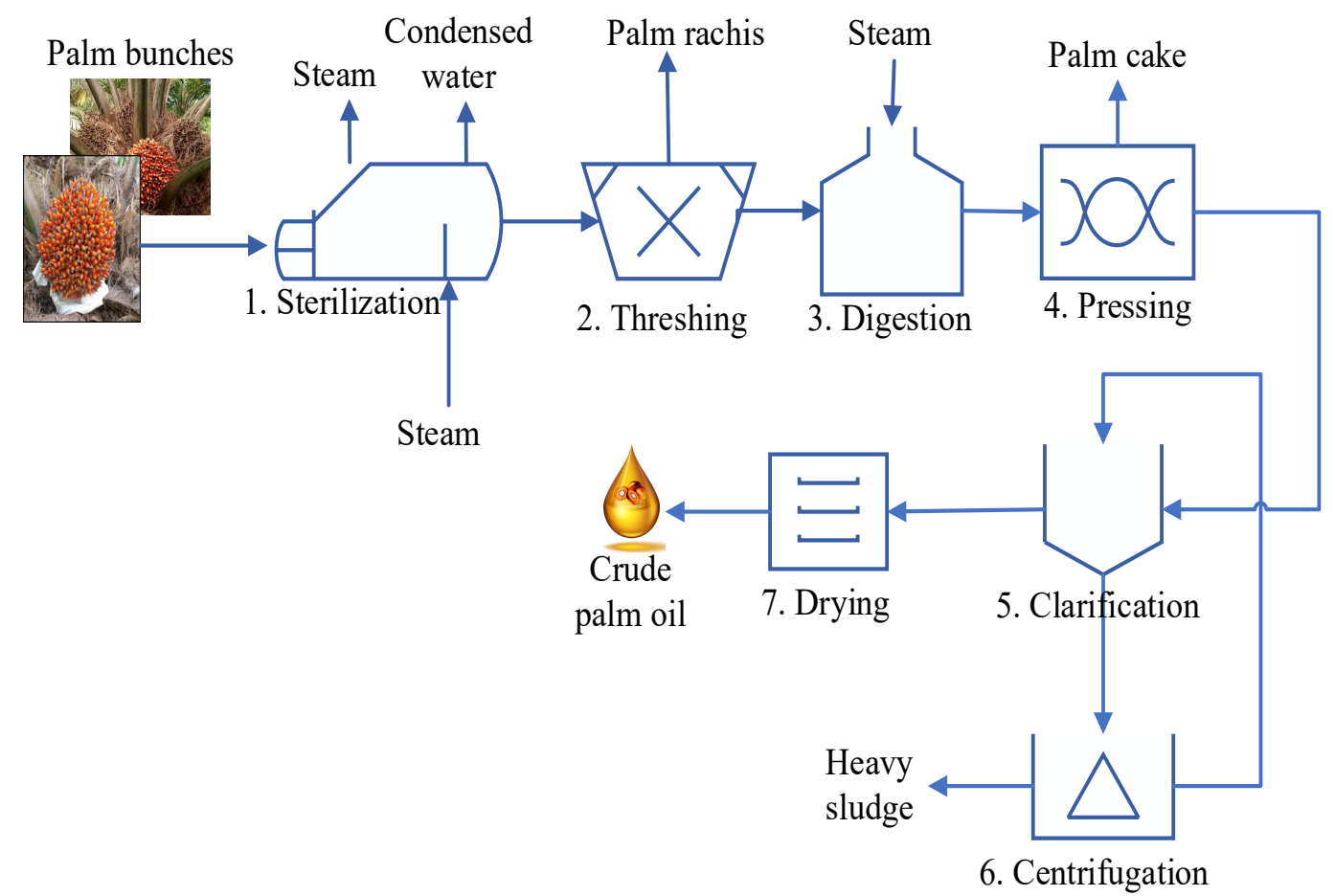

Figure 1. Process diagram for crude palm oil production. 


\subsection{Inherent Safety Analysis}

The safety analysis for the palm oil production process was developed and applied the ISI methodology based on the calculation of the total inherent safety index $\left(I_{T I}\right)$. The $I_{T I}$ was calculated by Equation (1) as the sum of the chemical safety index $\left(I_{C I}\right)$ and the process inherent safety index $\left(I_{P I}\right)$ [21]. A value of $I_{T I}$ higher than 24 for a process indicates that it is inherently unsafe, while lower values indicate that it is inherently safe [18]. Additionally, to determine the total inherent safety index, the worst-case scenario that may arise is evaluated.

$$
I_{T I}=I_{C I}+I_{P I}
$$

The chemical safety index is determined as shown in Equation (2) from the estimation of parameters associated with the nature of the chemical compounds involved in the process, while the process inherent safety index includes process variables as calculated by Equation (3). The information for the calculation of each subindex is presented in Table 2.

$$
\begin{gathered}
I_{C I}=I_{R M, \max }+I_{R S, \max }+I_{I N T, \max }+\left(I_{F L}+I_{E X}+I_{T O X}\right)_{\max }+I_{C O R, \max } \\
I_{P I}=I_{I}+I_{T, \max }+I_{P, \max }+I_{E Q, \max }+I_{S T, \max }
\end{gathered}
$$

\begin{tabular}{|c|c|c|c|}
\hline $\begin{array}{l}\text { Inherent Safety } \\
\text { Subindices }\end{array}$ & Symbol & Description & Score \\
\hline $\begin{array}{l}\text { Chemical } \\
\text { reactivity }\end{array}$ & $\begin{array}{l}I_{R M, \max } \\
I_{R S, \max }\end{array}$ & $\begin{array}{l}\text { Determined as the heat releases from the reactions that } \\
\text { take place within the process (primary and side) }\end{array}$ & $0-4$ \\
\hline $\begin{array}{l}\text { Chemical } \\
\text { interaction }\end{array}$ & $I_{I N T, \max }$ & $\begin{array}{c}\text { Determined considering the nondesired reactions, } \\
\text { which occur between the chemical species and } \\
\text { equipment materials }\end{array}$ & $0-4$ \\
\hline Flammability & $I_{F L}$ & Determined based on the flashpoint of the chemicals & $0-4$ \\
\hline Explosiveness & $I_{E X}$ & $\begin{array}{c}\text { Determined based on the explosion limits of } \\
\text { the chemicals }\end{array}$ & $0-4$ \\
\hline Toxic exposure & $I_{T O X}$ & Determined based on the toxicity of each chemical & $0-6$ \\
\hline Corrosiveness & $I_{C O R, \max }$ & $\begin{array}{l}\text { Determined based on the material selected for the } \\
\text { construction of the equipment }\end{array}$ & $0-2$ \\
\hline Inventory & $I_{I}$ & $\begin{array}{l}\text { Determined according to the mass contained in the } \\
\text { equipment for a retention time of } 1 \mathrm{~h}\end{array}$ & $0-5$ \\
\hline $\begin{array}{l}\text { Process } \\
\text { temperature }\end{array}$ & $I_{T, \max }$ & $\begin{array}{l}\text { Determined based on the maximum temperature } \\
\text { registered in the process }\end{array}$ & $0-4$ \\
\hline Process pressure & $I_{P, \max }$ & $\begin{array}{l}\text { Determined based on the maximum pressure } \\
\text { registered in the process }\end{array}$ & $0-4$ \\
\hline Equipment safety & $I_{E Q, \max }$ & Determined to evaluate the equipment in the process & $0-3$ \\
\hline $\begin{array}{l}\text { Safe process } \\
\text { structure }\end{array}$ & $I_{S T, \max }$ & $\begin{array}{l}\text { Determined according to information related to } \\
\text { accidents presented previously in the plant }\end{array}$ & $0-5$ \\
\hline
\end{tabular}

Table 2. Symbols and description for inherent safety subindices, adapted from [18].

\subsection{Sustainability Evaluation}

To determine the sustainable performance of the crude palm oil production process, the approach proposed in this study involves economic, environmental, energy, and safety parameters. The sustainable weighted return on investment metrics (SWROIM) is used to determine a single value that shows the overall sustainability performance of the process [24]. The calculation of this parameter follows the expression shown in Equations (4) and (5).

$$
\begin{gathered}
\text { SWROIM }=\frac{A S P}{T C I} \\
A S P=A E P\left[1+\sum_{i=1}^{\text {Nindicators }} w_{i}\left(\frac{\text { Indicator }_{i}}{\text { Indicator }_{i}^{\text {Target }}}\right)\right]
\end{gathered}
$$


TCI is the total capital investment, $A E P$ the annual net profit of the project, $w_{i}$ is the weighting factors of sustainability indicator $i$, Indicator $r_{i}$ and Indicator ${ }_{i}^{\text {Target }}$ are the current and target values of sustainability indicator $i$, respectively. The assignation of the values for $w_{i}$ depends on the priority of the decision makers [24]. A value $w_{i}=1$ for the weighting factor means that the parameter has the same relevance for the designer as the $A E P$; values below 1 are related to lower relevance, while values above 1 imply higher relevance. Among the advantages of this metric is the simplicity to estimate contributions of indicators to the economic performance of the system; however, the weighting factor may affect the objectivity of this approach. The indicators included in the sustainability evaluation of the palm oil production process are described as follows.

\subsection{Economic Indicators}

The techno-economic evaluation is used as a tool to determine the profitability of projects. Primary costs are evaluated as the sum of the total capital investment (TCI) and operating costs (OC) [25]. The total capital investment refers to the money needed for the purchase and installation of the plant [26]; while the operating costs are the money needed to maintain the operation of the plant. Return on investment is an economic indicator widely used to evaluate the profitability of engineering projects. It is defined by Equation (6) as the ratio between annual profit (after taxes) and total capital investment.

$$
\% \text { ROI }=\frac{\text { Annual profit }}{T C I} \times 100
$$

\subsection{Exergy Indicators}

Exergy is defined as the maximum theoretical work that can be performed from the interaction between a thermodynamic system and a reference environment [27]. Exergy indicates the energy quality [28], and in any chemical process, exergy is destroyed by irreversibilities. Exergy analysis allows the quantification of the thermodynamic irreversibilities of a process [29]; therefore, it is a useful tool to diagnose chemical operations, identifying the critical stages that contribute most to exergy destruction [30].

Exergy efficiency $\left(\eta_{\text {exergy }}\right)$ is a measure of process performance in terms of exergy flow as indicated in Equation (7), where $\dot{E} x_{\text {total, in }}$ is the total inlet exergy flow and $\dot{E} x_{\text {destroyed }}$ is the total exergy destroyed. Irreversibilities or exergy destroyed are calculated as the difference of the total inlet and total outlet product exergy flow. The exergy efficiency can be calculated for a section or unit of a chemical process [31].

$$
\eta_{\text {exergy }}=1-\left(\frac{\dot{E} x_{\text {destroyed }}}{\dot{E} x_{\text {total, in }}}\right)
$$

\subsection{Environmental Indicators}

The environmental assessment allows the evaluation of chemical processes to determine the possible environmental impacts and to propose solutions for sustainable development [32]. The Waste Reduction Algorithm (WAR) is a tool for evaluating the environmental performance of chemical processes [33]. The pondered sum of all impacts allows calculating a final value that measures the Potential Environmental Impact (PEI) [34]. This index is considered from two points of view, PEI output and PEI generated. The PEI output measures the environmental effects that the process emits and its main use to improve the capacity of the process to obtain final products with a minimum discharge of potential environmental impact [35]. Equation (8) shows the expression to calculate the total output rate of PEI on the mass of the product basis.

$$
I_{\text {out }}{ }^{(t)}=\frac{I_{\text {in }}{ }^{(c p)}+I_{g e n}{ }^{(c p)}}{\sum_{a} K_{k}}=\frac{\sum_{i} \alpha_{i} \sum_{j}^{c p} M_{j}^{(\text {out })} \sum_{a}^{c p} X_{a} \Psi_{a}+\sum_{j}^{e p-g} M_{j}^{(o u t)} \sum_{a}^{e p-g} X_{a} \Psi_{a}}{\sum_{k} K_{k}}
$$


where $I_{\text {out }}{ }^{(c p)}$ is the PEI output rates for the chemical process; $I_{\text {in }}{ }^{(c p)}$ and $I_{g e n}{ }^{(c p)}$ are the total inlet rate of PEI and the total generation of PEI, respectively. $M_{j}$ is the mass flow of the stream $j ; X_{a}$ is the mass fraction of a component an in the stream $j ; \Psi_{k}$ is the overall potential environmental impact of substance $a$.

Additionally, to determine the degree of improvement in environmental performance or percentage reduction in environmental impacts between a base case or base process and the environmentally improved process, Equation (9) is followed.

$$
\% R P E I_{\text {output }}=\left(\frac{\left(P E I_{\text {output }}\right)_{\max }-\left(P E I_{\text {output }}\right)_{i}}{\left(P E I_{\text {output }}\right)_{\max }}\right) \times 100 \%
$$

where $\left(P E I_{\text {output }}\right)_{\max }$ is the PEI output for the base process and $\left(P E I_{\text {output }}\right)_{i}$ is PEI output for the environmentally improved process.

\section{Results}

\subsection{Inherent Safety Analysis}

\subsubsection{Chemical Inherent Safety Index}

The results for the chemical safety index $\left(I_{C I}\right)$ are presented in Figure 2. In the crude palm oil extraction process, no reaction took place, thus the chemical reactivity subindex was null. The subindices of dangerous chemical substance $\left(I_{F L}+I_{E X}+I_{T O X}\right)_{\max }$ and chemical interaction $\left(I_{I N T, \max }\right)$ were calculated with information from the safety data sheet of the components. The subindex of dangerous chemical substance was estimated at 1 according to the fatty acids of palm oil are only combustible (flash point $>55^{\circ} \mathrm{C}$ ). The most dangerous chemical interaction is represented by the formation of nonflammable vapors, hence a score of 1 was assigned. Furthermore, the substances present in the process are not corrosive; therefore, no special material is required for the construction of the equipment and a score equal to 0 is assigned for the corrosion subindex. The inherent chemical safety index was estimated at 2.

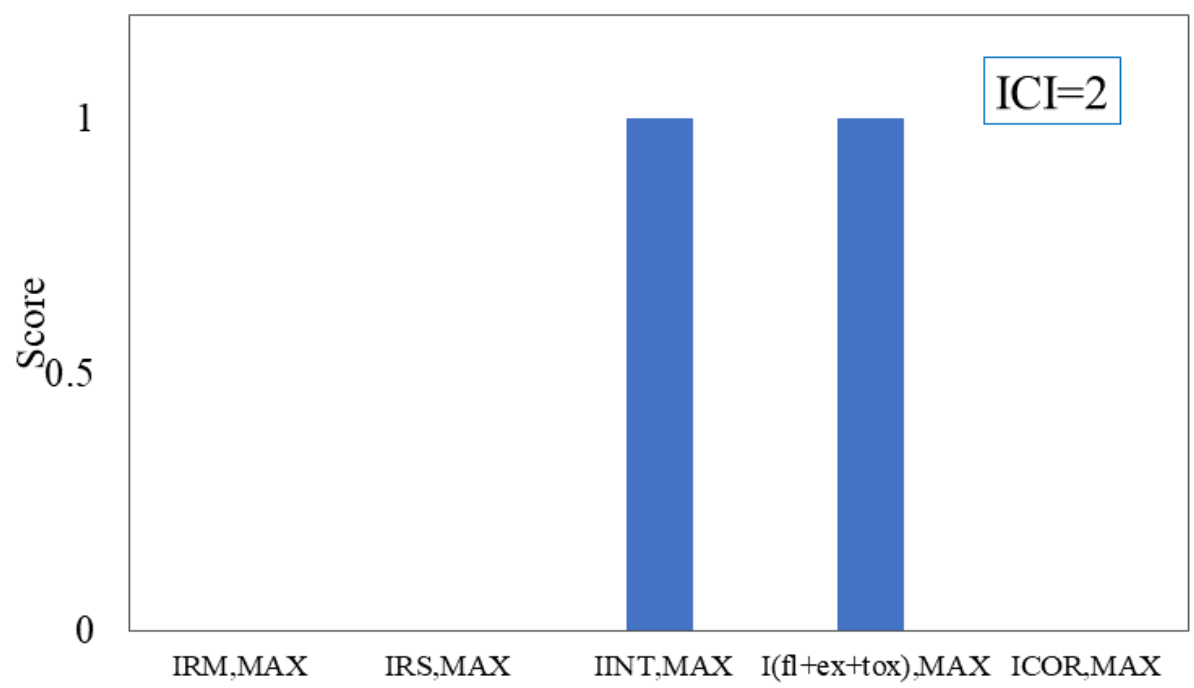

Figure 2. Calculated subindices for chemical inherent safety index and total score.

\subsubsection{Process Inherent Safety Index}

The results for the process safety index $\left(I_{P I}\right)$ are shown in Figure 3. To calculate the process safety index, the risk associated with the operating conditions, type of equipment, structures, and inventory was evaluated. The feedstock for the crude palm oil extraction process was estimated at approximately $134 \mathrm{t} / \mathrm{h}$; thus, the assigned score for the inventory subindex was 3 . The temperature and pressure subindices were determined according to the maximum temperature and pressure registered in the processes. The maximum temperature was registered in the digestion stage $\left(95^{\circ} \mathrm{C}\right)$; therefore, a score of 1 was 
assigned. The most critical pressures were reported in the oil dryer operating under vacuum conditions and in the steam streams that enter the sterilization and digestion stages at a pressure of $440 \mathrm{kPa}$. However, it was considered that the pressures do not represent any risk; therefore, the value of the pressure subindex is zero.

Another important factor in process safety is associated with the reliability of the equipment. The process equipment safety index was assigned a score of 4 as the most unsafe equipment in the process was the boiler and dryer. Finally, the safe structure subindex refers to the process safety from the engineering viewpoint; the crude palm oil production is a process already implemented; therefore, it is considered as a "common practice in engineering"; hence, it was assigned a score of 1 . The process safety index was calculated at 9 .

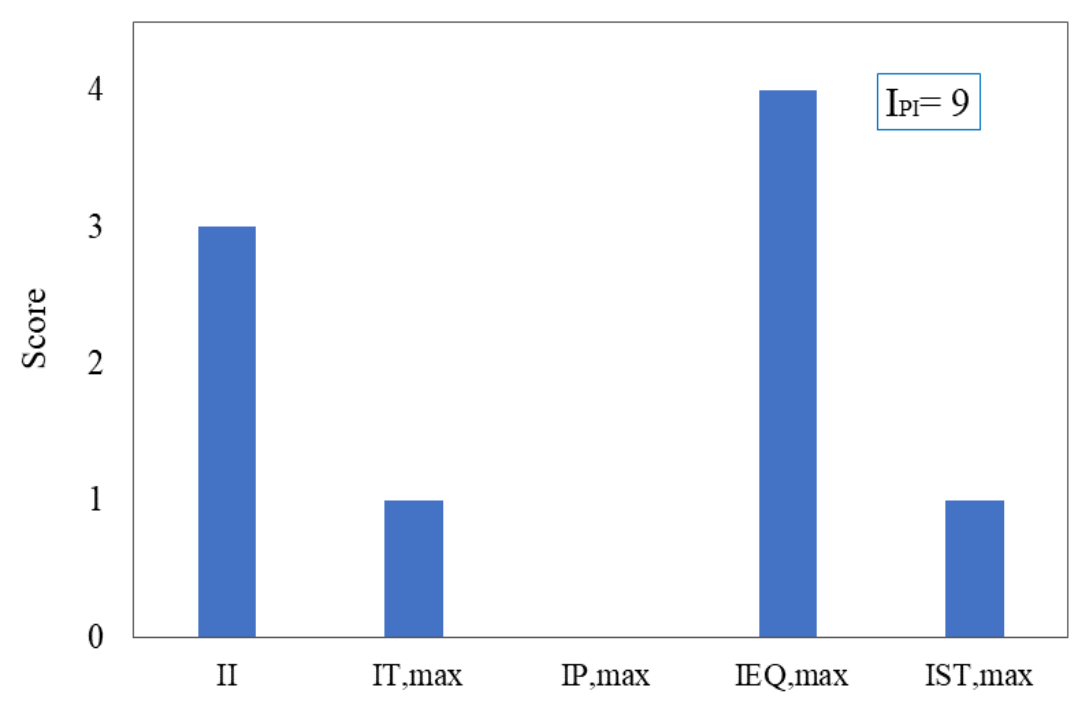

Figure 3. Calculated subindices for process inherent safety index and total score.

\subsubsection{Total Inherent Safety Index}

The total inherent safety index for the crude oil production process was 11 , as presented in Table 3.

Table 3. Total inherent safety index.

\begin{tabular}{cc}
\hline Index & Score \\
\hline $\mathrm{I}_{\mathrm{CI}}$ & 2 \\
$\mathrm{I}_{\mathrm{PI}}$ & 9 \\
$\mathrm{I}_{\mathrm{TI}}$ & 11 \\
\hline
\end{tabular}

\subsection{Sustainability Evaluation}

The economic indicator (ROI) for this process was obtained from the techno-economic analysis performed by Gonzalez Delgado [12]. The techno-economic evaluation was carried out using the same processing capacity presented in this study $(30 \mathrm{t} / \mathrm{y})$ for an annual production of 54,056 tons of crude palm oil. It was considered as a salvage value $10 \%$ of the fixed capital investment, 2 years for the construction of the plant, tax rate equal to $39 \%$, a discount rate of $9 \%$, useful life of the plant of 15 years, soft clay as a type of soil, 13 workers per shift with salaries of $30 \mathrm{USD} / \mathrm{h}$, and contingency percentage of $20 \%$, according to the context of the economy in Colombia. The key results are presented in Figure 4 . The ROI of $49.30 \%$ indicated that the project is economically attractive. 


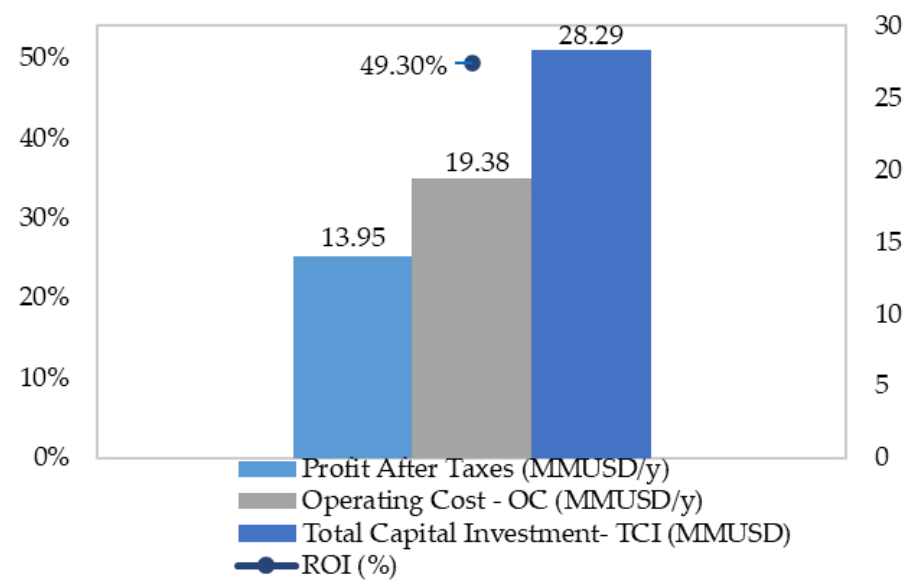

Figure 4. Summary of economic evaluation results for the crude oil production process, adapted from [12].

The indicator of exergy efficiency was taken from the exergy analysis performed by Martinez et al. [11]. The key results are presented in Figure 5.

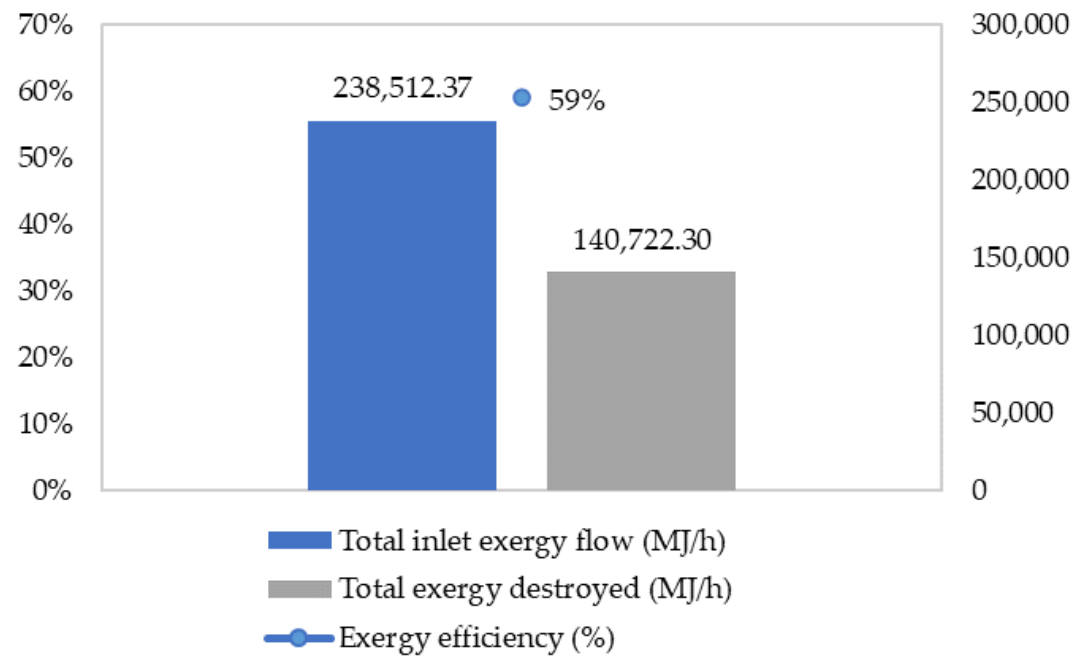

Figure 5. Exergy efficiency of the crude oil production process. Adapted from [11].

The total PEI output was obtained from the environmental analysis carried out by González-Delgado and Peralta-Ruiz [10]. Considerations for the assessment included the evaluation of four cases: case 1 without taking into account the energy and product stream contributions, case 2 , case 3 , and case 4 considering the product stream, process energy, and the amount of energy and product stream, respectively. The results are presented in Figure 6.

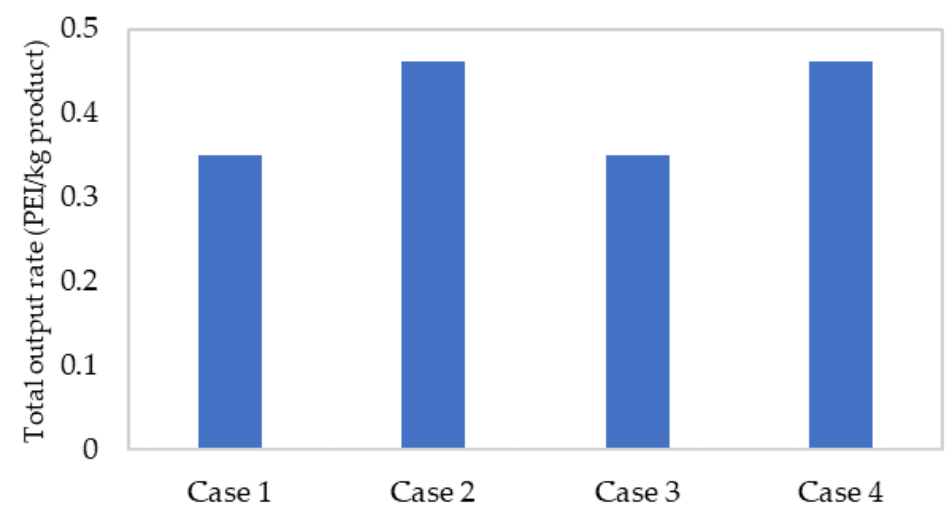

Figure 6. Total PEI output for crude palm oil production process, adapted from [10]. 
The value assigned for the safety parameter weighting factor $\left(w_{i}=1\right)$ was established considering that the risks associated with the process can put at risk the production, the facilities, the integrity of the personnel working in the plant, and the well-being of the neighboring communities [21]. Therefore, the process safety aspect must be maximal and equally relevant to the economic factor. A dangerous project affects the economy and the sustainability of the project; therefore, the safety indicator was established as negative in the SWROIM calculation. The weighting factor for the energy indicator $\left(w_{i}=1\right)$ was established considering the importance of energy consumption in the sustainability of processes. Finally, regarding the damage that the processes can produce to the environment and the commitments acquired by Colombia in terms of conservation and environmental protection, the environmental weighting factor $\left(w_{i}=1\right)$ was established as being of maximum relevance. In summary, for this project, the safety, energy, and environmental parameters were considered with the same relevance as the economic factor within the sustainability concept.

The application of SWROIM requires the definition of target indicators (indicator ${ }^{\text {target }}$ ) for each technical parameter. Furthermore, it needs the corresponding quantities of these parameters showing current process performance (indicator ${ }_{i}$ ). The objective for the safety parameter was established equal to the current performance, according to the consideration that a process is safe in terms of inherent risks when the $\mathrm{I}_{\mathrm{TI}}$ is lower than 24. In this case, the process has a safe performance; hence, it is not necessary to establish an objective value. For the energy parameter, the exergy efficiency of $100 \%$ was set as a target. The environmental targets are set according to the recommendation made by El-Halwagi [36], which suggests that comparative process techniques allow the targets of sustainability indicators to be established, taking into account the best results. Therefore, the indicator target is taken considering the maximum reduction in the output potential environmental impacts; for this work, a reduction of $50 \%$ of the output PEI was considered as the indicator target. The values for the weighting factors, indicators, and objective indicators are summarized in Table 4.

Table 4. Corresponding parameters, indicators, and the weighting factor for each technical parameter.

\begin{tabular}{ccccc}
\hline Aspect & Index & indicator $^{i}$ & indicator $^{\text {target }}$ & $\boldsymbol{w}_{\boldsymbol{i}}$ \\
\hline Safety & Total inherent safety index $\left(I_{T I}\right)$ & 11 & 11 & 1 \\
Energy & Exergy efficiency & $59 \%$ & $100 \%$ & 1 \\
Environmental & $\left(\% R\right.$ PEI $\left.I_{\text {output }}\right)$ & $24 \%$ & $50 \%$ & 1 \\
\hline
\end{tabular}

The sustainability evaluation for the crude palm oil production process shows a $53 \%$ return, which is higher than the value obtained for the return on investment $(49.30 \%)$. Furthermore, a sensitivity analysis was performed for the SWROIM changing the value considered for the technical parameter weighting factor to analyze the importance of each factor on the sustainability weighted return on investment metric. Three case studies were considered: the first case where the economic and energy aspects had the same relevance $\left(w_{i}=1\right)$ while the environmental and safety parameter value of 0.5 . A second case where the environmental factor was of equal relevance to the economic parameter $\left(w_{i}=1\right)$, and a third case where the technical factor of safety had equal relevance to the economic factor $\left(w_{i}=1\right)$. The results are presented in Figure 7. 


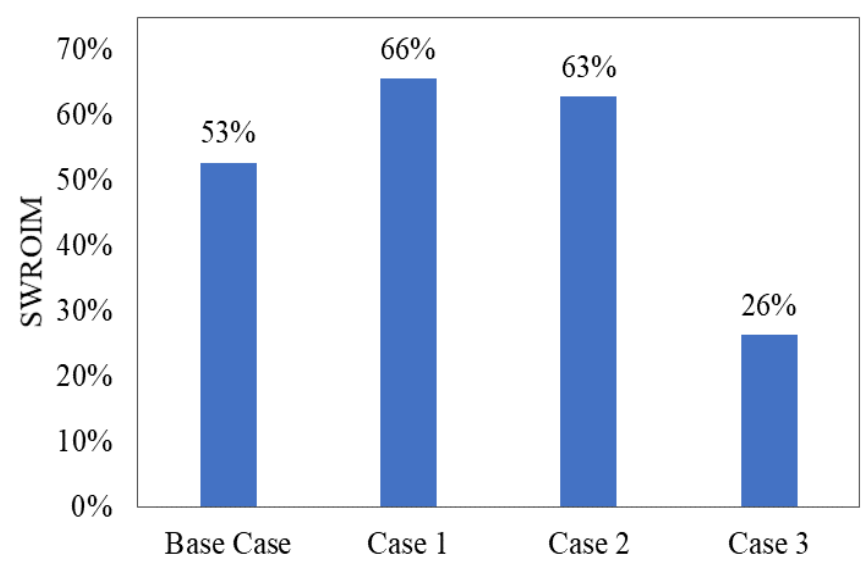

Figure 7. SWROIM sensitivity analysis.

\section{Discussion}

The chemical inherent safety index equal to 2 suggested that no highly dangerous substances are handled within the process in terms of toxicity, explosiveness, and flammability. This finding was compared with the results of inherent safety analysis reported in the literature for oil palm-based processes. Sanjuan et al. [19] reported an ICI of 18 for the production of bioethanol from palm raquis, which was attributed to the high value of index for heat of reactions, followed by flammability indicator. The extraction of crude palm oil reached lower CSI because of the nature of substances handled, which were less flammable, and the absence of reactions.

The process safety index shown in Figure 3 reached a value of 9, higher than the reported for bioethanol from rachis (5). The conditions that most affect the process safety are the high inventory and the safety of the equipment. Particularly, operation of unsafe equipment such as boiler and dryer supports this finding. Moreno-Sader et al. [14] also stated potential risks of fire and explosion in the boiler of CPO extraction systems, which could occur due to brittle failures, low water levels, excessive pressure, among others. The result reveals that crude palm oil extraction is an inherently safe process. The process safety index is higher than the chemical safety index, showing that the operating conditions are more critical. A comparison of the total inherent safety index achieved in a similar process shows that palm oil production has better performance from the safety point of view. The bioethanol production from palm rachis reported an $I_{T I}=23$ [19]; while a process for the production of levulinic acid reached an $I_{T I}=24$ [20]. The latter processes have exothermic chemical reactions and flammable solvents that contribute to the higher total inherent safety index compared to the $\mathrm{CPO}$ extraction. In general, the inherent safety analysis results suggest monitoring the oil drying oven and boiler operation to avoid any abnormal conditions.

Regarding the sustainability performance of the bioenergy system from palm oil, the economic dimension with $R O I=49.30 \%$ revealed promising profitability compared to other processes with lower return on investment. The CPO extraction system is higher than the minimum threshold value of $10 \%$ considered by different companies as reference [24]. Xuan Do et al. [37] reported lower ROI values of 4.59-21.69\% for three energy conversion pathways from empty fruit bunches that included bioethanol production, gasification, and fast pyrolysis.

The overall exergy efficiency at $59 \%$ indicates that the process is efficient from an energy point of view. Lower exergy destruction is observed for this system compared to other bioenergy processes such as bio-oil production from microalgae and lignocellulosic feedstocks. For example, Moreno-Sader et al. [38] evaluated the exergy performance of crude oil from Chlorella sp. microalge and reached an efficiency of 24\%. Gozmen Şanli et al. [39] reached exergy efficiencies ranging from $32.50 \%$ to $33.64 \%$ for a diesel engine using biodiesel from palm and opium poppy.

The total PEI output for crude palm oil production was higher for cases 2 and 4 $\left(4.61 \times 10^{-1}\right.$ and $4.61 \times 10^{-1}$, respectively) compared to cases 1 and $3\left(3.50 \times 10^{-1}\right.$ and 
$3.50 \times 10^{-1}$, respectively). The findings reveal that in the four cases the process does not emit a large number of environmental impacts and, therefore, has a good environmental performance. The environmental performance of the process achieved an improvement of $24 \%$ without considering contribution of the product stream on the emission of potential environmental impacts. Alvarez-Cordero et al. [15] reported environmental impacts of $1.66 \times 10^{-4} \mathrm{PEI} / \mathrm{h}$ for the dual production of CPO and kernel oil. Moreno-Sader et al. [38] reached values above $3.00 \times 10^{4} \mathrm{PEI} / \mathrm{h}$ for lignocellulosic bio-oil production.

The results shown in Figure 7 reveal that the energetic technical parameter is the most determined in the SWROIM result, considering the economic and energy factor of equal relevance, the highest value for the SWROIM is obtained (66\%). Hence, optimization strategies to reduce exergy losses must be included mainly. On the other hand, the safety indicator showed to be the weakest determinant on SWROIM, given that the current conditions are already safe. For future studies, other essential parameters can be considered concerning process characteristics and model objectives to allow a broader sustainability analysis. This result might mean that the evaluated technical parameters had positive effects that yield the economic performance of the plant. Notably, there is a positive contribution associated with the reduction in total PEI output and the increase in exergy efficiency. Additionally, this result compared to the SWROIM reported a lignocellulosic multifeedstock biorefinery where the same technical parameters are evaluated (27.29\%); in [21], it is revealed that the crude palm oil production plant presents more sustainable performance.

\section{Conclusions}

In this study, the inherent safety analysis and sustainability evaluation for the crude palm oil production process with a scenario in North Colombia was performed. From the results obtained, it can be concluded that the process is inherently safe. The highest risk was found in the drying stage; hence, it is recommended to monitor the operation of the dryer. Furthermore, the risk associated with the chemicals involved in the process was determined as negligible. The process is sustainable according to the SWROIM showed a yield of $53 \%$ which reveals that the technical parameters evaluated have a positive effect on the return on investment of the process. The energy parameter was the most determinant in this result with positive contributions associated with the increase in exergy efficiency. For future studies, other essential parameters could be considered concerning process characteristics and model objectives to allow a broader sustainability analysis. Furthermore, the application of process intensification techniques might positively contribute to the ongoing development of this sector.

Author Contributions: Conceptualization, A.D.G.-D.; methodology, A.F.B.-S., J.L.-P., and A.D.G.-D.; software, A.D.G.-D.; validation, A.F.B.-S., J.L.-P., and A.D.G.-D.; formal analysis, A.F.B.-S., J.L.-P., and A.D.G.-D.; investigation, A.F.B.-S., J.L.-P., and A.D.G.-D.; resources, A.F.B.-S., J.L.-P., and A.D.G.-D.; data curation, A.F.B.-S., J.L.-P., and A.D.G.-D.; writing-original draft preparation, A.F.B.-S., J.L.-P., and A.D.G.-D.; writing-review and editing, A.F.B.-S., J.L.-P., and A.D.G.-D.; visualization, A.D.G.-D.; supervision, A.D.G.-D. and J.L.-P.; project administration, A.D.G.-D.; funding acquisition, A.D.G.-D. All authors have read and agreed to the published version of the manuscript.

Funding: This research received no external funding.

Institutional Review Board Statement: Not applicable.

Informed Consent Statement: Not applicable.

Data Availability Statement: The data presented in this study are available in Gonzalez-Delgado and Peralta-Ruiz [12], Martinez et al. [11], and Gonzalez- Delgado and Peralta-Ruiz [10].

Acknowledgments: The authors express their gratitude to the University of Cartagena, Universidad Francisco de Paula Santander, and EAN University for providing equipment and software to conclude this research.

Conflicts of Interest: The authors declare no conflict of interest. 


\section{References}

1. Rivera-Méndez, Y.D.; Rodríguez, D.T.; Romero, H.M. Carbon footprint of the production of oil palm (Elaeis guineensis) fresh fruit bunches in Colombia. J. Clean. Prod. 2017, 149, 743-750. [CrossRef]

2. Fedepalma. Federación Nacional de Cultivadores de aceite palma -Fedepalma Statistical Yearbook 2015. In The Oil Palm Agroindustry in Colombia and the World 2011-2015; Área de Economía- UPSDS: Bogotá, Colombia, 2016.

3. Fedepalma. La palma de Aceite en Colombia. 2019. Available online: https://web.fedepalma.org/la-palma-de-aceite-encolombia-departamentos (accessed on 15 September 2020).

4. Ocampo-Peñuela, N.; Garcia-Ulloa, J.; Ghazoul, J.; Etter, A. Quantifying impacts of oil palm expansion on Colombia's threatened biodiversity. Biol. Conserv. 2018, 224, 117-121. [CrossRef]

5. Castiblanco, C.; Etter, A.; Ramirez, A. Impacts of oil palm expansion in Colombia: What do socioeconomic indicators show? Land Use Policy 2015, 44, 31-43. [CrossRef]

6. Rincón, L.E.; Moncada, J.; Cardona, C.A. Analysis of potential technological schemes for the development of oil palm industry in Colombia: A biorefinery point of view. Ind. Crop. Prod. 2014, 52, 457-465. [CrossRef]

7. Umar, M.S.; Urmee, T.; Jennings, P. A policy framework and industry roadmap model for sustainable oil palm biomass electricity generation in Malaysia. Renew. Energy 2018, 128, 275-284. [CrossRef]

8. Montoya, M.I.; Quintero, J.A.; Sánchez, Ó.J.; Cardona, C.A. Evaluación del impacto ambiental del proceso de obtención de alcohol carburante utilizando el algoritmo de reducción de residuos Environmental impact assessment for ethanol production process using the waste reduction algorithm. Rev. Fac. Ing. Univ. Antioq. 2006, 36, 85-95.

9. Ramirez-Contreras, N.E.; Munar-Florez, D.A.; Garcia-Nuñez, J.A.; Mosquera-Montoya, M.; Faaij, A.P.C. The GHG emissions and economic performance of the Colombian palm oil sector; current status and long-term perspectives. J. Clean. Prod. 2020, 258, 120757. [CrossRef]

10. González-Delgado, A.D.; Peralta-Ruíz, Y.Y. Environmental Assessment of a Crude Palm Oil Production Process under NorthColombian conditions Using WAR Algorithm. Int. J. ChemTech Res. 2016, 9, 833-843.

11. Martínez, D.; Puerta, A.; Mestre, R.; Peralta-Ruiz, Y.; Gonzalez-Delgado, A.D. Exergy-based evaluation of crude palm oil production in North-Colombia. Aust. J. Basic Appl. Sci. 2016, 10, 1-8.

12. González-Delgado, Á.; Peralta-Ruiz, Y. A hierarchical techno-economic sensitivity approach for evaluation of agroindustrial production chains. Int. J. ChemTech Res. 2017, 10, 921-929.

13. Subramaniam, V.; Hashim, Z.; Loh, S.K.; Astimar, A.A. Assessing water footprint for the oil palm supply chain- a cradle to gate study. Agric. Water Manag. 2020, 237, 106184. [CrossRef]

14. Moreno-Sader, K.; Alarcón-Suesca, C.; González-Delgado, Á.-D. Application of environmental and hazard assessment methodologies towards the sustainable production of crude palm oil in North-Colombia. Sustain. Chem. Pharm. 2020, 15, 1-10. [CrossRef]

15. Alvarez-Cordero, A.; De Avila-Alvis, Y.; Ortiz-Rincon, M.; González-Delgado, A.; Peralta-Ruiz, Y. Environmental Assessment of Dual Crude Palm and Kernel Oil Production in North-Colombia using WAR Algorithm. J. Eng. Appl. Sci. 2017, 12, 7265-7271.

16. Munasinghe, M.; Jayasinghe, P.; Deraniyagala, Y.; Matlaba, V.J.; dos Santos, J.F.; Maneschy, M.C.; Mota, J.A. Value-Supply Chain Analysis (VSCA) of crude palm oil production in Brazil, focusing on economic, environmental and social sustainability. Sustain. Prod. Consum. 2019, 17, 161-175. [CrossRef]

17. Oliveira-Rodrigues, T.; Caldeira-Pires, A.; Luz, S.; Albuquerque-Frate, C. GHG balance of crude palm oil for biodiesel production in the northern region of Brazil. Renew. Energy 2014, 62, 516-521. [CrossRef]

18. Heikkilä, A. Inherent safety in process plant design. VTT Publ. 1999, 384, 1-132.

19. Sanjuan, M.; Tobon, K.; Meramo-Hurtado, S.; Ojeda, K.; Gonzalez, Á. Bioethanol Production Process from Palm Rachis Using the Computer-Assisted Intrinsic Safety Index Method. Int. J. Acad. Eng. Res. 2018, 2, 8-11.

20. Meramo-Hurtado, S.I.; Ojeda, K.A.; Sanchez-Tuiran, E. Environmental and Safety Assessments of Industrial Production of Levulinic Acid via Acid-Catalyzed Dehydration. ACS Omega 2019, 4, 22302-22312. [CrossRef]

21. Meramo-Hurtado, S.I.; Sanchez-Tuiran, E.; Ponce-Ortega, J.M.; El-Halwagi, M.M.; Ojeda-Delgado, K.A. Synthesis and Sustainability Evaluation of a Lignocellulosic Multifeedstock Biorefinery Considering Technical Performance Indicators. ACS Omega 2020, 5 , 9259-9275. [CrossRef]

22. Denny, K.S.; Wendy, P.Q.; Mei, F.; David, L. Waste Recovery and Regeneration (REGEN) system for palm oil industry. Chem. Eng. Trans. 2015, 45, 1315-1320.

23. Owolarafe, O.K.; Faborode, M.O. Micro-structural characterisation of palm fruit at sterilisation and digestion stages in relation to oil expression. J. Food Eng. 2008, 85, 598-605. [CrossRef]

24. Guillen-Cuevas, K.; Ortiz-Espinoza, A.P.; Ozinan, E.; Jiménez-Gutiérrez, A.; Kazantzis, N.K.; El-Halwagi, M.M. Incorporation of Safety and Sustainability in Conceptual Design via a Return on Investment Metric. ACS Sustain. Chem. Eng. 2018, 6, 1411-1416. [CrossRef]

25. El-Halwagi, M. Chapter 2-Overview of Process Economics. In Sustainable Design through Process Integration; Elsevier: Amsterdam, The Netherlands, 2012; p. 1561.

26. Herrera-Rodriguez, T.; Parejo-Palacio, V.; González-Delgado, Á.D. Technoeconomic sensibility analysis of industrial agar production from red algae. Chem. Eng. Trans. 2018, 70, 2029-2034. 
27. Peralta-Ruiz, Y.; Saavedra, D.; González-Delgado, A. Exergy based evaluation of large-scale hydrogen production from African palm rachis. Aust. J. Basic Appl. Sci. 2016, 10, 168-175.

28. Abusoglu, A.; Kanoglu, M. Exergetic and thermoeconomic analyses of diesel engine powered cogeneration: Part 1-Formulations. Appl. Therm. Eng. 2009, 29, 234-241. [CrossRef]

29. Restrepo-serna, D.L.; Anderson, J.; Cardona-alzate, C.A. Energy Efficiency of Biorefinery Schemes Using Sugarcane Bagasse as Raw Material. Energies 2018, 11, 3474. [CrossRef]

30. Meramo-Hurtado, S.; Urbina-Suarez, N.; González-Delgado, Á. Computer-aided environmental and exergy analyses of a large-scale production of chitosan microbeads modified with TiO2 nanoparticles. J. Clean. Prod. 2019, 273, 117804. [CrossRef]

31. Meramo-Hurtado, S.I.; Gonzalez-Delgado, A.D.; Rehmann, L.; Quiñones, E.; Mehrvar, M. Comparison of Biobutanol Production Pathways via Acetone-Butanol-Ethanol Fermentation Using a Sustainability Exergy-Based Metric. ACS Omega 2020, in press. [CrossRef]

32. Cardenas, Y.; Orozco, I.; González, A.; Kafarov, V. Enviromental Assessment of Microalgae Biosiesel Production in Colombia: Comparison of Three oil Extraction Systems. Latinoam. J. Oil Gas Altern. Energy 2013, 5, 85-100.

33. Meramo-Hurtado, S.; Alarcón-Suesca, C.; González-Delgado, Á.D. Exergetic sensibility analysis and environmental evaluation of chitosan production from shrimp exoskeleton in Colombia. J. Clean. Prod. 2020, 248, 119285. [CrossRef]

34. Carvajal, J.C.; Gómez, A.; Cardona, C.A. Comparison of lignin extraction processes: Economic and Environmental assessment. Bioresour. Technol. 2016, 214, 468-476. [CrossRef] [PubMed]

35. Meramo, S.I.; Bonfante, H.; De Avila-Montiel, G.; Herrera-Barros, A. Environmental Assessment of a Large-Scale Production of TiO2 Nanoparticles via Green Chemistry. Chem. Eng. Trans. 2018, 70, 1063-1068.

36. El-Halwagi, M.M. Sustainable Design through Process Integration: Fundamentals and Applications to Industrial Pollution Prevention, Resource Conservation, and Profitability Enhancement; Butterworth-Heinemann: Oxford, UK, 2012; ISBN 9781856177443.

37. Do, T.X.; Lim, Y. Techno-economic comparison of three energy conversion pathways from empty fruit bunches. Renew. Energy 2016, 90, 307-318. [CrossRef]

38. Moreno-Sader, K.; Meramo-Hurtado, S.I.; González-Delgado, A.D. Computer-aided environmental and exergy analysis as decision-making tools for selecting bio-oil feedstocks. Renew. Sustain. Energy Rev. 2019, 112, 42-57. [CrossRef]

39. Gozmen Şanli, B.; Uludamar, E.; Özcanli, M. Evaluation of energetic-exergetic and sustainability parameters of biodiesel fuels produced from palm oil and opium poppy oil as alternative fuels in diesel engines. Fuel 2019, 258, 116116. [CrossRef] 